\title{
Pengaruh Kompos Batang Pisang Terhadap Pertumbuhan dan \\ Hasil Tanaman Terung (Solanum melongena, L.) \\ Pada Tanah Podsolik Merah Kuning
}

\section{Nurhadiah, Ona Sutra \\ Fakultas Pertanian Universitas Kapuas Sintang}

\begin{abstract}
Abstrak : Kompos sebagai salah satu bahan organik tanah, dapat memperbaiki sifatsifat tanah. Salah satu jenis tanah yang kurang bahan organiknya adalah tanah podsolik merah kuning (PMK). Untuk membudidayakan tanaman, seperti tanaman terung pada tanah PMK, perlu adanya penambahan bahan organik diantaranya kompos batang pisang. Penelitian ini dilakukan untuk mengetahui pengaruh kompos batang pisang terhadap pertumbuhan dan hasil tanaman terung pada tanah PMK, serta untuk mendapatkan dosis kompos batang pisang yang akan memberikan pertumbuhan dan hasil tanaman terung yang tinggi. Penelitian ini menggunakan Rancangan Acak Kelompok (RAK) dengan perlakuan adalah kompos batang pisang yang terdiri dari 7 taraf perlakuan dan diulang 4 kali, adapun taraf perlakuan yang dimaksud yaitu: tanpa kompos batang pisang $\left(\mathrm{p}_{0}\right), 0,5 \mathrm{~kg}$ kompos batang pisang per $\mathrm{m}^{2}\left(\mathrm{p}_{1}\right), 1 \mathrm{~kg}$ kompos batang pisang per $\mathrm{m}^{2}\left(\mathrm{p}_{2}\right), 1,5 \mathrm{~kg}$ kompos batang pisang per $\mathrm{m}^{2}\left(\mathrm{p}_{3}\right), 2 \mathrm{~kg}$ kompos batang pisang per $\mathrm{m}^{2}\left(\mathrm{p}_{4}\right), 2,5 \mathrm{~kg}$ kompos batang pisang per $\mathrm{m}^{2}\left(\mathrm{p}_{5}\right), 3 \mathrm{~kg}$ kompos batang pisang per $\mathrm{m}^{2}\left(\mathrm{p}_{6}\right)$. Jumlah tanaman yang diamati dalam penelitian ini sebanyak 112 tanaman. Adapun peubah yang diamati yaitu tinggi tanaman, jumlah buah dan berat buah. Penelitian dilaksanakan bulan Maret sampai Juli 2016, di Kecamatan Sekadau Hilir. Hasil penelitian menunjukkan bahwa kompos batang pisang berpengaruh terhadap pertumbuhan dan hasil tanaman terung pada tanah PMK, yang ditandai dengan tinggi tanaman dan berat buah. Pemberian $3 \mathrm{~kg}$ kompos batang pisang menghasilkan tinggi tanaman tertinggi dengan rata-rata $89,44 \mathrm{~cm}$, sedangkan hasil yang ditunjukkan dari berat buah tertinggi terjadi pada pemberian $1 \mathrm{~kg}$ dengan berat buah rata-rata 162,81 gram per tanaman.
\end{abstract}

Kata Kunci: kompos batang pisang, terung, pertumbuhan, hasil.

\section{PENDAHULUAN}

Pisang (Musa paradisiaca L.) merupakan tanaman buah-buahan yang tumbuh dan tersebar di seluruh Indonesia. Indonesia merupakan negara penghasil pisang terbesar di Asia. Pisang dikatagorikan menjadi 3 golongan yaitu pisang yang dapat dikonsumsi, pisang yang diambil pelepah batangnya sebagai serat dan pisang yang dipergunakan sebagai tanaman hias (Sriharti dan Salim, 2008). Dalam pemanfaatannya sebagai konsumsi, tentu akan menghasilkan limbah. Limbah ini masih dapat dimanfaatkan untuk menghasilkan produk-produk yang berguna dan memberi nilai ekonomi yang cukup tinggi, diantaranya sebagai bahan baku pembuatan kompos. 
Kompos sebagai salah satu bahan organik tanah, dapat memperbaiki sifat-sifat tanah. Secara garis besar, bahan organik memperbaiki sifat - sifat tanah meliputi sifat fisik, kimia dan biologi tanah. Bahan organik memperbaiki sifat fisik tanah dengan cara membuat tanah menjadi gembur sehingga aerasi menjadi lebih baik serta mudah ditembus perakaran tanaman. Bahan organik pada tanah yang bertekstur pasir akan meningkatkan pengikatan antar partikel dan meningkatkan kapasitas mengikat air. Sifat kimia tanah diperbaiki dengan meningkatnya kapasitas tukar kation dan ketersediaan hara, sedangkan pengaruh bahan organik pada biologi tanah adalah menambah energi yang diperlukan untuk kehidupan mikroorganisme tanah (Hakim dkk, 1989).

Salah satu jenis tanah yang kurang bahan organiknya adalah tanah podsolik merah kuning (PMK). Menurut Syarief (1986:136), kandungan bahan organik tanah PMK terutama pada lapisan atas (top soil) adalah kurang dari 9\% dan umumnya 5\%, kandungan unsur hara rendah serta $\mathrm{pH}$ tanah sangat rendah yaitu 4,0 - 5,5. Untuk membudidayakan tanaman, seperti tanaman terung pada tanah PMK, perlu adanya penambahan bahan organik diantaranya kompos batang pisang. Batang pisang yang digunakan sebagai kompos, bahan bakunya mudah didapat dan relatif tidak memerlukan biaya untuk memperolehnya. Selain ketersediaan yang cukup, kompos batang pisang mengandung unsur hara Nitrogen $0.88 \%$, Fosfor 0.655 , Kalium 0.92\%, KTK 64 me/100g dan C/N rasio 13 (Balai Penelitian Tanah, 2008:10), dan memiliki kemampuan menahan air yang sangat besar (Suryani, 2010:33). Kekurangan pada tanah PMK di kabupaten Sekadau, diduga dapat diatasi dengan penambahan kompos batang pisang.

Penambahan kompos batang pisang diharapkan dapat meningkatkan produksi tanaman sayuran, terutama tanaman terung dimana produksi kabupaten Sekadau masih rendah, dibandingkan produksi kabupaten Sintang. Berdasarkan data BPS Kabupaten Sekadau tahun 2015, jumlah produksi rata-rata terung di Sekadau hanya 0,84 ton/ha/tahun, sedangkan rata-rata produksi di kabupaten Sintang 7,59 ton/ha/tahun. Menurut Isroi (2008), kompos memperbaiki struktur tanah dengan meningkatkan 
kandungan bahan organik tanah.

Tanaman yang dipupuk dengan kompos juga cenderung lebih baik kualitasnya daripada tanaman yang dipupuk dengan pupuk kimia, misalnya: hasil panen lebih tahan disimpan, lebih berat, lebih segar, dan lebih enak. Penelitian ini dilakukan untuk mengetahui pengaruh kompos batang pisang terhadap pertumbuhan dan hasil tanaman terung pada tanah PMK, serta untuk mendapatkan dosis kompos batang pisang yang akan memberikan pertumbuhan dan hasil tanaman terung yang tinggi.

\section{METODOLOGI PENELITIAN}

Penelitian ini menggunakan Rancangan Acak Kelompok (RAK) dengan perlakuan adalah kompos batang pisang yang terdiri dari 7 taraf perlakuan dan diulang 4 kali, adapun taraf perlakuan yang dimaksud yaitu: tanpa kompos batang pisang $\left(\mathrm{p}_{0}\right), 0,5$ $\mathrm{kg}$ kompos batang pisang per $\mathrm{m}^{2}\left(\mathrm{p}_{1}\right)$, $1 \mathrm{~kg}$ kompos batang pisang per $\mathrm{m}^{2}$ $\left(\mathrm{p}_{2}\right), 1,5 \mathrm{~kg}$ kompos batang pisang per $\mathrm{m}^{2}\left(\mathrm{p}_{3}\right), 2 \mathrm{~kg}$ kompos batang pisang per $\mathrm{m}^{2}\left(\mathrm{p}_{4}\right), 2,5 \mathrm{~kg}$ kompos batang pisang per $\mathrm{m}^{2}\left(\mathrm{p}_{5}\right), 3 \mathrm{~kg}$ kompos batang pisang per $\mathrm{m}^{2}\left(\mathrm{p}_{6}\right)$.

Pada penelitian ini satuan percobaan berjumlah 112 tanaman, terdiri dari 7 taraf kompos batang pisang x 4 ulangan x 4 tanaman. Satuan pengamatan adalah seluruh tanaman percobaan. Adapun peubah yang diamati yaitu tinggi tanaman, jumlah buah dan berat buah. Penelitian dilaksanakan bulan Maret sampai Juli 2016, di Kecamatan Sekadau Hilir.

Bahan-bahan yang digunakan dalam penelitian ini, yaitu: Benih tanaman terung varietas lezata, batang pisang, pupuk kandang, insektisida dan fungisida. Sedangkan alat yang digunakan, yaitu: cangkul, timbangan, alat ukur, dan gembor.

\section{HASIL DAN PEMBAHASAN}

\section{Hasil Penelitian}

\section{Tinggi Tanaman}

Hasil pengamatan terhadap tinggi tanaman dianalisis dengan menggunakan analisis sidik ragam, dapat dilihat pada Tabel 1. 
Tabel 1. Analisis sidik ragam pengaruh kompos batang pisang terhadap tinggi tanaman $(\mathrm{cm})$

\begin{tabular}{lcccccc}
\hline \multicolumn{1}{c}{ SK } & \multirow{2}{*}{ DB } & \multirow{2}{*}{ JK } & KT & F-hit & \multicolumn{2}{c}{ F-tab } \\
\cline { 6 - 7 } & & & & & $\mathbf{0 . 0 5}$ & $\mathbf{0 . 0 1}$ \\
\hline Kelompok & 3 & 115,31 & 38,44 & $2,07^{\text {tn }}$ & 3,16 & 5,09 \\
Perlakuan & 6 & 1265,74 & 210,96 & $11,36^{* *}$ & 3,66 & 4,01 \\
Galat & 18 & 334,21 & 18,57 & & & \\
\hline Total & $\mathbf{2 7}$ & $\mathbf{1 7 1 5 , 2 6}$ & & $\mathbf{k k}=$ & $\mathbf{5 , 1 6 \%}$ &
\end{tabular}

Sumber : Hasil analisis data, 2016

Keterangan : tn $=$ tidak bepengaruh nyata

$* *$ = berpengaruh sangat nyata

Hasil analisis sidik ragam (Tabel

1) menunjukkan bahwa perlakuan

kompos batang pisang berpengaruh

sangat nyata terhadap tinggi tanaman.
Untuk mengetahui level perlakuan mana yang terbaik, maka dilanjutkan dengan uji Beda Nyata Jujur (BNJ), yang disajikan pada Tabel 2 .

Tabel 2. Uji BNJ pengaruh kompos batang pisang terhadap tinggi tanaman (cm)

\begin{tabular}{cccccccc}
\hline Perlakuan & Rerata & Beda & & & & & \\
\hline $\mathrm{p}_{0}$ & $67,56 \mathrm{a}$ & - & & & & & \\
$\mathrm{p}_{2}$ & $84,13 \mathrm{~b}$ & $16,56^{* *}$ & - & & & & \\
$\mathrm{p}_{1}$ & $84,50 \mathrm{~b}$ & $16,94^{* *}$ & $0,38^{\text {tn }}$ & - & & & \\
$\mathrm{p}_{4}$ & $85,75 \mathrm{bc}$ & $18,19^{* *}$ & $1,63^{\text {tn }}$ & $1,25^{\text {tn }}$ & - & & \\
$\mathrm{p}_{5}$ & $86,63 \mathrm{bc}$ & $19,06^{* *}$ & $2,50^{\text {tn }}$ & $2,13^{\text {tn }}$ & $0,88^{\text {tn }}$ & - & \\
$\mathrm{p}_{3}$ & $86,81 \mathrm{bc}$ & $19,25^{* *}$ & $2,69^{\text {tn }}$ & $2,31^{\text {tn }}$ & $1,06^{\text {tn }}$ & $0,19^{\text {tn }}$ & - \\
$\mathrm{p}_{6}$ & $89,44 \mathrm{c}$ & $21,88^{* *}$ & $5,32^{*}$ & $4,94^{*}$ & $3,69^{\text {tn }}$ & $2,81^{\text {tn }}$ & $2,63^{\text {tn }}$ \\
\hline BNJ 0,05 = & $\mathbf{4 , 6 1}$ & & & & & & \\
BNJ 0,01 = & $\mathbf{5 , 8 0}$ & & & & & &
\end{tabular}

Keterangan : Nilai rerata yang diikuti oleh huruf yang sama bearti tidak berbeda nyata pada selang kepercayaan $95 \%$

Uji BNJ (Tabel 2) menunjukkan bahwa pemberian kompos batang pisang sebanyak $3 \mathrm{~kg} / \mathrm{m}^{2}$ menghasilkan rerata tinggi tanaman lebih tinggi dibandingkan dengan level perlakuan lainnya, dengan rerata tinggi tanaman $89,44 \mathrm{~cm}$. 
Jumlah Buah

Hasil pengamatan terhadap

jumlah buah dianalisis dengan menggunakan analisis sidik ragam, dapat dilihat pada Tabel 3.

Tabel 3. Analisis sidik ragam pengaruh kompos batang pisang terhadap jumlah buah per tanaman (buah)

\begin{tabular}{lcccccc}
\hline \multicolumn{1}{c}{ SK } & \multirow{2}{*}{ DB } & \multirow{2}{*}{ JK } & KT & F-hit & \multicolumn{2}{c}{ F-tab } \\
\cline { 6 - 7 } & & & & & $\mathbf{0 . 0 5}$ & $\mathbf{0 . 0 1}$ \\
\hline Kelompok & 3 & 1,24 & 0,41 & $0,86^{\text {tn }}$ & 3,16 & 5,09 \\
Perlakuan & 6 & 3,89 & 0,65 & $1,35^{\text {tn }}$ & 3,66 & 4,01 \\
Galat & 18 & 8,67 & 0,48 & & & \\
\hline Total & $\mathbf{2 7}$ & $\mathbf{1 3 , 7 9}$ & & $\mathbf{k k}=\mathbf{2 4 , 7 5 \%}$ \\
\hline
\end{tabular}

Sumber : Hasil analisis data, 2016

Keterangan $:$ tn $=$ tidak bepengaruh nyata

Hasil analisis sidik ragam (Tabel

3) menunjukkan bahwa perlakuan

kompos batang pisang tidak

berpengaruh nyata terhadap jumlah

buah.

\section{Berat Buah}

Hasil pengamatan terhadap berat buah dianalisis dengan menggunakan analisis sidik ragam, dapat dilihat pada Tabel 4.

Tabel 4. Analisis sidik ragam pengaruh kompos batang pisang terhadap berat buah per tanaman $(\mathrm{g})$

\begin{tabular}{lcccccc}
\hline \multicolumn{1}{c}{ SK } & \multirow{2}{*}{ DB } & \multirow{2}{*}{ JK } & \multirow{2}{*}{ KT } & F-hit & \multicolumn{2}{c}{ F-tab } \\
\cline { 6 - 7 } & & & & & $\mathbf{0 . 0 5}$ & $\mathbf{0 . 0 1}$ \\
\hline Kelompok & 3 & 1526,20 & 508,73 & $0,32^{\text {tn }}$ & 3,16 & 5,09 \\
Perlakuan & 6 & 50560,90 & 8426,82 & $5,33^{* *}$ & 3,66 & 4,01 \\
Galat & 18 & 28440,62 & 1580,03 & & & \\
\hline Total & $\mathbf{2 7}$ & $\mathbf{8 0 5 2 7 , 7 1}$ & & $\mathbf{k k}=$ & $\mathbf{2 4 , 9 2 \%}$ & \\
\hline
\end{tabular}

Sumber : Hasil analisis data, 2016

Keterangan : tn $=$ tidak bepengaruh nyata

$* *=$ berpengaruh sangat nyata

Hasil analisis sidik ragam (Tabel

4) menunjukkan bahwa perlakuan kompos batang pisang berpengaruh sangat nyata terhadap berat buah. Untuk 
mengetahui level perlakuan mana yang terbaik, maka dilanjutkan dengan uji
Beda Nyata Jujur (BNJ), yang disajikan pada Tabel 5 .

$\underline{\text { Tabel 5. Uji BNJ pengaruh kompos batang pisang terhadap berat buah per tanaman (g) }}$

\begin{tabular}{cccccccc}
\hline Perlakuan & Rerata & Beda & & & & & \\
\hline $\mathrm{p}_{0}$ & $83,44 \mathrm{a}$ & - & & & & & \\
$\mathrm{p}_{1}$ & $112,19 \mathrm{a}$ & $28,75^{\text {tn }}$ & - & & & & \\
$\mathrm{p}_{2}$ & $162,81 \mathrm{~b}$ & $79,38^{* *}$ & $50,63^{*}$ & - & & & \\
$\mathrm{p}_{3}$ & $163,06 \mathrm{~b}$ & $79,63^{* *}$ & $50,88^{*}$ & $0,25^{\text {tn }}$ & - & & \\
$\mathrm{p}_{4}$ & $193,25 \mathrm{~b}$ & $109,81^{* *}$ & $81,06^{* *}$ & $30,44^{\text {tn }}$ & $30,19^{\text {tn }}$ & - & \\
$\mathrm{p}_{5}$ & $198,88 \mathrm{~b}$ & $115,44^{* *}$ & $86,69^{* *}$ & $36,06^{\text {tn }}$ & $35,81^{\text {tn }}$ & $5,63^{\text {tn }}$ & - \\
$\mathrm{p}_{6}$ & $203,13 \mathrm{~b}$ & $119,69^{* *}$ & $90,94^{* *}$ & $40,31^{\text {tn }}$ & $40,06^{\text {tn }}$ & $9,88^{\text {tn }}$ & $4,25^{\text {tn }}$ \\
\hline
\end{tabular}

$\begin{array}{ll}\text { BNJ 0,05 }= & 42,53 \\ \text { BNJ 0,01 }= & 53,46\end{array}$

Keterangan : Nilai rerata yang diikuti oleh huruf yang sama bearti tidak berbeda nyata pada selang kepercayaan $95 \%$

Hasil uji BNJ seperti yang terlihat dalam Tabel 5 diketahui bahwa berat buah tanaman terung pada tanah PMK yang dihasilkan oleh tanaman yang diberi $3 \mathrm{~kg}$ kompos batang pisang tidak lebih berat dari buah tanaman yang diberi $2,5 \mathrm{~kg}, 2 \mathrm{~kg}, 1,5 \mathrm{~kg}$ dan 1 $\mathrm{kg}$, tetapi lebih berat dari buah tanaman yang diberi $0,5 \mathrm{~kg}$ kompos batang pisang dan tanaman kontrol.

\section{Pembahasan}

Hasil analisis data diketahui bahwa pemberian kompos batang pisang berpengaruh nyata terhadap tinggi tanaman dan berat buah. Hal ini diduga karena kompos batang pisang berfungsi dalam memperbaiki sifat fisik dan kimia tanah, dengan kondisi fisik tanah yang baik menyebabkan akar tanaman bekerja dan berkembang secara optimal sehingga penyerapan unsur hara yang ada di dalam tanah juga berlangsung dengan baik. Pemberian kompos batang pisang juga menambah bahan organik tanah sehingga keberadaan unsur hara bagi tanaman menjadi tersedia dengan baik dalam proses pertumbuhan dan perkembangan tanaman terung.

Pemberian kompos batang pisang tidak berpengaruh nyata terhadap jumlah buah per tanaman, ini diduga karena unsur-unsur hara yang terdapat dalam kompos batang pisang oleh tanaman terung lebih ke pembentukan 
sel-sel dalam buah, dari pada pembentukan jumlah buah. Ini terlihat dari ukuran buah yang cenderung lebih besar.

Hasil uji BNJ menunjukkan bahwa pemberian $3 \mathrm{~kg}$ kompos batang pisang tinggi tanaman yang lebih baik dari yang diberi $0,5 \mathrm{~kg}, 1 \mathrm{~kg}$, dan yang tidak diberi kompos batang pisang, tetapi tidak lebih tinggi dari tinggi tanaman yang diberi $1,5 \mathrm{~kg}, 2,5 \mathrm{~kg}, 2$ $\mathrm{kg}$. Hal ini diduga bahwa pemberian 1,5 kg kompos batang pisang cukup optimal dalam mempengaruhi ukuran sel tanaman terung terutama dalam perpanjangan sel. Perubahan ukuran sel ini sangat bergantung pada ketersediaan karbohidrat yang optimum bagi tanaman. Menurut Harjadi (1991:103), pembelahan sel pada fase vegetatif sangat tergantung pada persediaan karbohidrat.

Hasil uji BNJ juga diketahui bahwa pemberian $3 \mathrm{~kg}$ kompos batang pisang tidak menghasilkan berat buah yang lebih tinggi dari buah tanaman yang diberi $2,5 \mathrm{~kg}, 2 \mathrm{~kg}, 1,5 \mathrm{~kg}$ dan 1 $\mathrm{kg}$, tetapi lebih berat dari buah tanaman yang diberi $0,5 \mathrm{~kg}$ kompos batang pisang dan tanaman kontrol. Pemberian $1 \quad \mathrm{~kg}$ kompos batang pisang menghasilkan berat buah per tanaman yang tidak berbeda dengan berat buah tanaman yang diberi $1,5-3 \mathrm{~kg}$ diduga pada dosis $1 \mathrm{~kg}$ menyebabkan kondisi tanah menjadi baik untuk perkembangan biologi tanah, dan ketersediaan $\mathrm{N}, \mathrm{P}$, dan $\mathrm{K}$ meningkat. Hanafiah, dkk (2008:137-140) menjelaskan bahwa perbaikan kondisi biologi tanah akan meningkatkan pertumbuhan dan hasil tanaman. Hakim, dkk. (1986:121) menjelaskan bahwa kondisi biologi tanah yang membaik akan memperbaiki tata udara dalam tanah, akibat selanjutnya pertumbuhan tanaman akan meningkat. Lakitan (2001:67-69) menjelaskan bahwa unsur $\mathrm{N}$, $\mathrm{P}$, dan $\mathrm{K}$ merupakan unsur hara yang paling banyak diperlukan oleh tanaman. Ketersediaan unsur $\mathrm{N}$, $\mathrm{P}$, dan $\mathrm{K}$ yang cukup akan meningkatkan pertumbuhan tanaman.

Pada pemberian $3 \mathrm{~kg}, 2.5 \mathrm{~kg}$, dan $1.5 \mathrm{~kg}$ kompos batang pisang tidak menghasilkan berat buah lebih tinggi dari pemberian $1 \mathrm{~kg}$ diduga karena pelepasan unsur hara dari kompos batang pisang menjadi unsur hara yang tersedia bagi tanaman terung berlangsung lamban. Menurut Tola dkk, (2007:1-8) bahwa pemberian pupuk organik pada dosis yang tinggi tidak disertai dengan pertumbuhan dan hasi 
ltanaman karena sifatnya dalam menyediakan unsur hara bagi tanaman bersifat sangat lambat.

\section{KESIMPULAN DAN SARAN}

Hasil penelitian menunjukkan bahwa kompos batang pisang berpengaruh terhadap pertumbuhan dan hasil tanaman terung pada tanah PMK, yang ditandai dengan tinggi tanaman dan berat buah. Pemberian $3 \mathrm{~kg}$ kompos batang pisang menghasilkan tinggi tanaman tertinggi dengan rata-rata $89,44 \mathrm{~cm}$, sedangkan hasil yang ditunjukkan dari berat buah tertinggi terjadi pada pemberian $1 \mathrm{~kg}$ dengan berat buah rata-rata 162,81 gram per tanaman.

\section{DAFTAR PUSTAKA}

Hakim, N. Nyakpa, M.Y., Lubis, A.M., Nugroho, S.G., Saul, M.R., Diha, M.A., Hong, G.B., H.H. 1986. Dasar-Dasar Ilmu Tanah. Universitas Lampung. Lampung Harjadi, M.M.S.S. 1997. Pengantar Agronomi. PT. Gramedia Pustaka Utama. Jakarta
Isroi.2008. Kompos. Balai Penelitian Tanah Jakarta.

Lakitan, B. 2001.FisiologiTumbuhan. RajawaiPressindo. Jakarta

Madjid, A. R. 2009. Kesuburan Tanah Bahan Ajar Online. Fakultas Pertanian Unsri \& Program Pascasarjana Unsri.

Sriharti dan T. Salim. 2008. Pemanfaatan Limbah Pisang Untuk Pembuatan Kompos Menggunakan Komposter Rotary Drum. Prosiding Seminar Nasional Teknoin. Yogyakarta

Suryani, A. 2010. Kompos Batang Pisang. Bogor: IPB. diakses tanggal 24 Januari 2016.

Sutanto, R. 2002. Penerapan Pertanian Organik (Pemasyarakatan dan Pengembangannya). Kanisius. Yogyakarta

Syarief, ES. 1986. Ilmu Tanah Pertanian. Bandung: Pustaka Buana

Tola., F. Hamzah., Dahlan., Kaharudin. 2007. Pengaruh Penggunaan Dosis Pupuk Bokashi Kotoran Sapi Terhadap Pertumbuhan dan Produksi Tanaman Jagung. Jurnal Agrisistem. Vol. 3.No. 1.Juni 2007. 